\title{
Industrial Dynamics and Clusters: A Survey
}

\section{Koen Frenken, Elena Cefis \& Erik Stam}

To cite this article: Koen Frenken, Elena Cefis \& Erik Stam (2015) Industrial Dynamics and Clusters: A Survey, Regional Studies, 49:1, 10-27, DOI: 10.1080/00343404.2014.904505

To link to this article: http://dx.doi.org/10.1080/00343404.2014.904505

$$
\text { 册 Published online: } 16 \text { May } 2014 .
$$

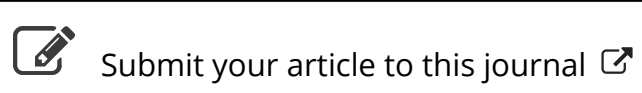

\footnotetext{
Џll Article views: 726
}

Q View related articles $₫$

View Crossmark data $\nearrow$

4 Citing articles: 8 View citing articles 


\title{
Industrial Dynamics and Clusters: A Survey
}

\author{
KOEN FRENKEN*, ELENA CEFIS† and ERIK STAM $\ddagger$ \\ *Innovation Studies, Copernicus Institute of Sustainable Development, Utrecht University, PO Box 80115, \\ NL-3508TC Utrecht, the Netherlands.Email:k.frenken@uu.nl \\ †Department of Management, Economics and Quantitative Methods, University of Bergamo, Via dei Caniana, 2, \\ I-24127Bergamo, Italy.Email: elena.cefis@unibg.it \\ $\ddagger$ Utrecht University School of Economics (USE), Utrecht University, PO Box 80125, NL-3508TC Utrecht, the Netherlands. \\ Email:e.stam@uu.nl
}

(Received October 2011; in revised form February 2014)

Frenken K., Cefis E. and Stam E. Industrial dynamics and clusters: a survey, Regional Studies. This paper reviews the literature on clusters and their effects on the entry, exit and growth of firms as well on the evolutionary dynamics underlying the process of cluster formation. This extensive review shows that there is strong evidence that clusters promote entry, but little evidence that clusters enhance firm growth and firm survival. From a number of open questions various future research avenues are distilled that stress the importance of firm heterogeneity and the exact mechanisms underlying localization economies.

Entry Exit Industrial cluster Localization economies Evolutionary economic geography Firm heterogeneity

FRENKEN K., CeFIS E. and STAM E. 工业动态与群聚：一份调查，区域研究。本文回顾群聚及其对于厂商进入、退出、成 长之影响，以及支撑群聚形成过程之演化动态的文献。此一广泛的回顾，显示出群聚促进厂商进入的强力证据，但有 关群聚能够促进厂商成长与生存的证据却相当薄弱。本研究从若干开放式问题，萃取出强调厂商异质性的重要性、以 及支撑地方化经济之确切机制的各种未来研究路径。

\section{进入 退出工业群聚＼cjkstart地方化经济＼cjkstart演化经济地理厂商异质性}

Frenken K., Cefis E. et Stam E. La dynamique industrielle et les clusters: une enquête, Regional Studies. Cet article fait la critique de la documentation sur les clusters et leurs effets sur l'entrée, la sortie et la croissance des entreprises ainsi que sur la dynamique évolutionniste qui sous-tend le processus de création des clusters. Cette critique exhaustive montre que tout indique que les clusters encouragent l'entrée, mais il y a peu d'indications que les clusters augmentent la croissance et la survie des entreprises. À partir d'un nombre de questions ouvertes, on détermine diverses pistes de recherche futures qui soulignent l'importance de l'hétérogénéité des entreprises et les mécanismes précis qui sous-tendent les économies de localisation.

Entrée Sortie Cluster industriel Économies de localisation Géographie économique évolutionniste Hétérogénéité des entreprises

Frenken K., Cefis E. und Stam E. Branchendynamik und Cluster: eine Erhebung, Regional Studies. In diesem Beitrag untersuchen wir die Literatur über Cluster und ihre Auswirkung auf die Gründung, die Schließung und das Wachstum von Firmen sowie über die evolutionäre Dynamik, die dem Prozess der Clusterbildung zugrunde liegt. Aus dieser ausführlichen Überprüfung geht hervor, dass zahlreiche Belege für eine Förderung von Firmengründungen, aber nur wenige Belege für eine Verbesserung des Wachstums und Überlebens von Firmen durch Cluster vorliegen. Anhand einer Reihe von offenen Fragen arbeiten wir verschiedene künftige Forschungsrichtungen heraus, bei denen die Wichtigkeit der Firmenheterogenität und die genauen Mechanismen von Lokalisierungsökonomien besonders betont werden.
Firmengründungen
Firmenschließungen
Industrielle Cluster
Lokalisationsökonomien
Evolutionäre
Wirtschaftsgeografie Heterogenität von Firmen

Frenken K., Cefis E. y Stam E. Dinámicas y agrupaciones industriales: una encuesta, Regional Studies. En este artículo analizamos la bibliografia sobre las agrupaciones y sus efectos en la creación, el cierre y el crecimiento de las empresas, así como sobre las dinámicas evolutivas que subyacen al proceso de formación de agrupaciones. En este exhaustivo análisis se muestra que existen fuertes evidencias de que las agrupaciones fomentan la creación de empresas, pero no parece que aumente el crecimiento ni la supervivencia de las empresas. A partir de varias preguntas abiertas se desprenden posibles vías de investigación futuras en las que se resalta la importancia de la heterogeneidad empresarial y los mecanismos subyacentes exactos de las economías de localización. 
Creación de empresas Cierre de empresas Aglomeración industrial Economías de localización Geografía económica evolutiva Heterogeneidad empresarial

JEL classifications: L10, L20, L26, R10

\section{INTRODUCTION}

The field of industrial dynamics is a relatively young field of study (CARLSSON, 1987), yet has roots in the classic works of Alfred Marshall, Joseph Schumpeter and Edith Penrose. Its main topic is the evolution of industries with a focus on entry, growth and exit of firms (CARlsson, 1987, 1989; MALERBA, 2006, 2007). In contrast to the neoclassical approach to industries - commonly referred to as industrial organization industrial dynamics solely focuses on phenomena that are inherently dynamic, and deals with these in an interdisciplinary manner. One of the disciplines with which there is increasing cross-fertilization is economic geography.

At the interface of industrial dynamics and economic geography, the central question holds:

How can the emergence of spatial clusters of economic activity be understood from the entry, growth and exit of firms, and how, in turn, do clusters affect entry, growth and exit patterns through localization economies?

A cluster is defined here as a spatial concentration of firms operating in the same industry. These questions are not only of academic interest, but also of policy interest as high rates of entry and exit are generally associated with growth in employment and productivity (for a recent review, see FRITSCH, 2011). The understanding of how clusters emerge and how these in turn affect rates of entry and exit has become a core question among economists and geographers alike. Witnessing the increase in theoretical and empirical studies in this 'interface field', time has come to take stock of the progress made so far and the questions that still remain. ${ }^{1}$

The field of industrial dynamics can be delineated in both a broad sense and a narrow sense (MALERBA, 2007). In a broad sense, the field deals with all questions related to the process of industrial transformation including the growth of firms, entry and exit dynamics, the co-evolution of technology, market structure and institutions, and the impact of structural change on macroeconomic growth (CARLSSON, 1989) as well as the analysis of changes in demand, the knowledge base of industries, and the structure and dynamics of innovation networks (MALERBA, 2007). In a narrow sense, industrial dynamics can be taken to refer to the demography of industries in terms of the dynamics of entry, growth and exit of firms underlying the growth and decline of industries, where entry can be broken down into de novo start-ups, diversifiers and spinoffs, and exit into merger, acquisition and failure. For the purpose of this survey, it was chosen to define the field of industrial dynamics in the narrow demographic sense, as to be able to provide a systematic and comprehensive review.

Following the aforementioned definition of the interface between industrial dynamics and economic geography as the study 'how entry, growth and exit of firms lead to spatial clustering, and how, in turn, clusters affect entry and exit patterns through localization economies', a review naturally is structured in two parts. The first part will deal with the latter question how localization economies affect entry, exit and growth (in the second section). This part is mainly empirical and focuses on the core question whether there is conclusive evidence on the existence of localization economies. The other part applies a long-term perspective and deals with the question of how clusters emerge and evolve over time (in the third section). This part will look more closely at spatial clustering as an evolutionary process and, theoretically, is linked to evolutionary economic geography (BOSCHMA and FRENKEN, 2006; Martin and Sunley, 2006). The paper discusses the spatial product life cycle approach where the location of new industries and their relocation dynamics are derived from underlying patterns of technological change, as well as the more recent industry life cycle approach and its emphasis on spinoffs dynamics leading to the formation of clusters. The paper ends with a short summary of the main findings and the conclusions that can be drawn from these (in the fourth section). From this, a discussion follows on future avenues for research (in the fifth section).

\section{INDUSTRIAL DYNAMICS AND LOCALIZATION ECONOMIES}

For a long time, academic scholars have dealt with questions of firm entry, growth and exit without taking into account the spatial context in which firms are operating. More recently, many ask the following question: how does the geographic distribution of industrial activity affect entry, exit, and growth of firms within that same industry? In particular, there is a broadly shared notion that a spatial concentration of firms in the same industry - otherwise referred to as clusters - would help entrepreneurs in setting up firms (firm entry), expanding its output (firm growth) and avoid closing down a firm (firm exit). Advantages of co-location of firms operating in the same industry are commonly referred to as localization economies. ${ }^{2}$ 
Most studies have focused on estimating whether there is an association between localization and industrial dynamics (here, firm entry, firm growth or firm exit), i.e. whether localization economies can be identified, without further probing the exact underlying mechanisms or sources of firm heterogeneity (RIGBY and BROWn, 2013; vAN OORT et al., 2012). Furthermore, there is the difficulty of assessing whether clusters raise firm performance or whether well-performing firms create a cluster, e.g. through spinoffs, or both (Boschma and Wenting, 2007; Klepper, 2007). Hence, a statistical association between clustering and a particular industrial dynamic, if any, should never be conflated with a simple causal relationship.

\section{Firm entry}

Firm entry is the result of the interaction between the characteristics of an actor, on the one hand, and the surrounding environment, on the other hand.

Although some individuals start a business without prior experience in the business in which they operate, they are the exception rather than the rule. Most entrepreneurs have accumulated relevant experience as an employee and display 'sectoral inertia', i.e. they start their firm as a spinoff in an industry with which they already were familiar as an employee (STOREy, 1982; LlOyd and Mason, 1984; VivarELLI, 1991). Far from the universal choice, entrepreneurial action is relatively constrained: instead of looking around to seek the most profitable opportunity, the potential entrepreneur concentrates his attention on a familiar sector. A person working in an industry is more likely to identify a market gap than a person without any industry experience, irrespective of the degree of industry competition and growth prospects (Shane, 2000; AgArwal et al., 2004; Gompers et al., 2005; KLEPPER, 2009).

Since entrepreneurs typically build on their prior experience when founding a firm, the existing economic structure greatly affects the rate of entry in a region. That is, the more firms are active in a particular industry in a particular region, the more new firms will be created in that same industry and region. In the field of organizational ecology, closely related to the field of industrial dynamics (BOONE and VAN WitTeloosTUIJN, 1995; GEROSKI, 2001), the positive effect of the number of incumbents on entry is more generally known as a social legitimation effect. Legitimation is generally loosely defined as 'social taken-for-grantedness' (HANNAN et al., 1995) and is assumed to rise with the number of incumbents in an industry, known as 'firm density'. When measured at the regional level, firm density thus is a variable indicating the extent of clustering as it measures the spatial concentration of firms.

There are two main processes underlying social legitimation. First, the current stock of firms in a region generates business information that diffuses to potential entrepreneurs inducing them to start the same type of business, termed 'cognitive legitimacy' (ALDRICH and FIOL, 1994, p. 648). A prime mechanism of cognitive legitimacy is the knowledge transfer that takes place between incumbent and entrepreneur before the latter creates a spinoff company (SORENSON and Audia, 2000). A recent study showed that an individual is more likely to become an entrepreneur if co-workers have been entrepreneurs before, reflecting better access to information and resources that help identify entrepreneurial opportunities, and peer effects from co-workers' perceptions about entrepreneurship as a career choice (NANDA and Sørenson, 2010). Apart from cognitive legitimacy, socio-political legitimacy is also expected to rise with the number of incumbents. Socio-political legitimation refers 'to the process by which key stakeholders, the general public, key opinion leaders, or government officials accept a venture as appropriate and right, given existing norms and laws' (ALDRICH and FiOL, 1994, p. 648). Indeed, it has been found that entrepreneurs in a region provide social role models with the presence of other firms that have 'made it', and a cultural environment where establishing one's own business is normal and failure is not a social stigma (FORNAHL, 2003; VAILLANT and LAFUENTE, 2007).

From the aforementioned processes of legitimation, one would predict that the more firms in a particular industry are present in a region, the higher the regional entry rates in that industry (BIGELOW et al., 1997; VAN WISSEN, 2004). Put differently, one expects entry rates to rise with cluster size, where a cluster is defined as a spatial concentration of firms in the same industry. Empirical evidence is indeed strong. In a comprehensive study covering more than half a million firm entries across all sectors in the United States, it was found that the higher the number of firms in a region, the higher its number of entries, both at the level of the entire economy and at the level of six broad economic sectors (ACs and ARMINGTON, 2002) and more narrowly defined industries (NySTRÖM, 2007). Furthermore, numerous industry studies have found that regional firm density affects regional entry rates. This includes studies on industries such as automobile (Bigelow et al., 1997), computer (BAPTISTA and Swann, 1999), footwear (Sorenson and Audia, 2000), accounting (CATTANi et al., 2003), biotechnology (STUART and SOREnSON, 2003), motorcycles (WeZEl, 2005), fashion houses (WENTING and Frenken, 2011), and video games (DE VAAN et al., 2011). ${ }^{3}$

Many interpret the association between localization and entry rates as evidence of localization economies, i.e. of benefits firms accrue from co-locating with firms in the same industry. Localization economies include the advantages of specialized labour markets, specialized suppliers and knowledge spillovers (MARSHALL, 1920) 
as well as reduced costs of experimentation (DURANTON and PUGA, 2001). Such benefits may attract new entrants to clusters, apart from traditional regional cost conditions that affect location decisions (such as transaction costs, transportation costs and shared infrastructures). However, if the founder of a firm was already located in a cluster, the positive association between clustering and entry rates may simply reflect the high economic and social cost of relocation (STAM, 2007). Indeed, in studies on tyres (BUENSTORF and KlePper, 2009) and lasers (Buenstorf and GeissLER, 2011), no evidence was found that entrants are drawn to clusters because of the presence of other firms, once controlling for their regional origins. Most founders prefer to locate in the region in which they are already located, reflecting the high costs of relocation (FIGUEIREDO et al., 2002) as well as social ties (DAHL and SORENSON, 2012). ${ }^{4}$

\section{Firm growth}

Though there is a strong association between spatial clustering and firm entry, it has been argued here that this association does not provide clear evidence of localization economies. As most entrepreneurs do not relocate when they found their own firm, the association between clustering and entry most probably reflects spatial inertia more than anything else. The impact of localization economies can better be assessed by associating clustering directly to indicators of firm performance, including firm growth (this subsection) and firm survival (see the next subsection).

Relatively few studies on localization economies and firm growth have been carried out so far. One of the most comprehensive studies on firm growth and localization economies is that by BEAUDRY and SWANN (2009) on firm growth in 56 two-digit industries in the UK. In about half of these industries, there is a positive and statistically significant association between firm growth and own-sector employment. Significant associations between firm growth and total employment in other sectors (an indicator of 'urbanization economies') are less common, but where these arise these associations are generally negative. Cluster effects are strongest in manufacturing and infrastructure industries, but weaker in services. MAINE et al. (2010) take a somewhat different approach by testing the effect of distance to the nearest top-ten cluster on growth of firms in particular high-technology industries, finding a negative effect of distance on firm growth, but no effect of being located within a cluster, suggesting that location within a cluster might also incur localization diseconomies (e.g. knowledge leakage).

Other studies looked at firm growth of young firms specifically. For example, Rosenthal and STRANGE (2005) investigated all new plants in the greater New York metropolitan area in 2001 and found that specialization, measured as location quotients, was positively related to job creation among new firms. Similarly, WENNBER G and LindQVist (2010) analysed firm-level data for Swedish firms started in the telecom and consumer electronics, financial services, information technology, medical equipment, and pharmaceuticals and pharmaceutical sectors, and found evidence for localization economies when using absolute measures (firm density or employee counts), yet evidence was substantially weaker when using location quotients as measures for localization economies. Note here that localization economies are best captured by absolute counts rather than by location quotients as benefits of co-location in clusters are expected to rise with the absolute number of co-located firms in the same industry irrespective of the country-wide distribution of firms. ${ }^{5}$

\section{Firm survival}

The studies that examine firm survival are usually based on survival or duration analysis which deals with firm death/exit from the market. Survival analysis involves the modelling of time to event data; in this context, the exit of the firm is considered an event in the survival analysis literature. The survival probability is therefore the complementary probability of the exit probability and those factors that positively affect survival probabilities (i.e., increase the firm chances to survive), at the same time negatively affect the exit probability (i.e., decrease the firm chances to exit the market).

Several empirical studies in industrial dynamics document the impact of the firm's specific characteristics and industry features on firm's survival. Survival probability of firms, and consequently the probability to exit the market, varies less across industrial sectors than entry rates (Geroski, 1995; Audretsch et al., 1999, 2000). This fact has been interpreted as evidence that barriers to survival are higher than barriers to entry: it is easier to start a firm than to survive (GEROSKI, 1995). These barriers to survival have been primarily related to structural factors, such as firm size and age (e.g. Evans, 1987; Hall, 1987; Doms et al., 1995, Geroski, 1995; Sutton, 1997; Caves, 1998); and to traditional market structure variables, such as the presence of scale economies, other cost advantages of established firms and the growth rate of sector specific demand (Audretsch, 1991; Audretsch and Mahmood, 1995; Dunne and Hughes, 1994; Mata and Portugal, 1994; Wagner, 1994). Some studies have also highlighted the role of technological conditions in an industry as a determinant of firm survival (Audretsch, 1991, 1995; AgARWAL, 1998), while others have focused on the role of innovative activities, looking at the intensity of research and development (R\&D) expenditure (HALL, 1987; Esteve Perez et al., 2004), and indicators of innovative performance (CEFIS and MARSILI, 2005, 2006). 
Compared with the few studies on localization and firm growth, the literature on localization and firm survival is much richer. Undoubtedly, this reflects the fact that data on firm survival are easier to collect than data on firm growth. However, whereas the little evidence on firm growth seems to point to localization economies, the evidence of such economies on firm survival is rather weak, if not even opposite to the hypothesis that localization entails positive externalities.

Studies comparing different industries typically find evidence for localization economies for some industries only. For example, Nyström (2007), using a panel data of Swedish firms, shows that localization increases firm survival only in 16 out of 26 industries. Similarly, RENSKI (2011) found that industrial localization has a positive influence on new firm survival in five out of eight industries examined. The aforementioned studies by Rosenthal and Strange (2005) and WennBERG and LINDQVIST (2010) on firm growth also found evidence for localization economies on firm survival. Note, however, that these results can be biased in the sense that only new firms are analysed.

There are also studies that find neither a positive nor a negative effect of clustering. In series of studies looking at firm survival in particular industries, including the US car industry (KLEPPER, 2007), the global fashion design industry (WENTING, 2008), the US tyre industry (BUenstorf and Klepper, 2009), the US semiconductor industry (KLEPPER, 2010), the German machine tool industry (Buenstorf and Guenther, 2011), and the Dutch publishing industry (HEEBELS and Boschma, 2011), firms in clusters did not survive longer than firms outside clusters. Importantly, the absence of cluster effects in all these studies becomes apparent only when controlling for pre-entry experience attributed to spinoffs. This means that clusters typically host more successful firms, yet this success does not stem from clustering, but from the experience entrepreneurs have gained working as an employee before they started their firm.

Finally, there are studies that present evidence that clustering is detrimental for firm survival. In their study on the US footwear industry, SORENSON and Audia (2000) found firm density to affect survival negatively. Similarly, Staber (2001) showed that firm density increased business failure rates of knitwear firms in Baden-Wurttemberg, Germany. STUART and SORENSON (2003) obtained the same result for US biotechnology firms, though in this study other forms of agglomeration economies were found to be survivalenhancing. Looking at services in the United States, Acs et al. (2007) found for new firms that location in specialized regions is detrimental for survival. Similarly, in a long-term study of the British car industry, Boschma and Wenting (2007) showed that firm density at the time of founding lowered survival rates.

A more subtle approach to the measurement of cluster effects is to distinguish between same-industry and related-industry effects. As many clusters consist of a set of related industries (PORTER, 1998), it can be analysed whether same-industry concentration and relatedindustry concentration have different effects on firm survival. It would be expected that while firms may suffer from co-location with close competitors in the same industry, they may profit from co-location with related industries in vertical relations or as sources of cross-sectoral knowledge spillovers (CANTWELL and SAntangelo, 2002; Frenken et al., 2007). Indeed, STABER's (2001) analysis of survival of knitwear firms in Baden-Wurttemberg showed that location in clusters of firms in the same industry increased business failure rates, while location in diversified clusters of firms operating in complementary industries reduced failure rates. Similarly, in a long-term study of the British car industry, BoschmA and WeNTING (2007) showed that firms had lower survival rates when founded in clusters, but higher survival rates in regions with high levels of employment in related industries. And in a study on plant survival in Sweden (1970-2004), NefFKe et al. (2012) found no evidence for localization economies, while the local presence of technologically related industries substantially increased survival rates of plants.

In all, despite some studies presenting positive evidence, most studies on clustering and firm survival find little evidence for the Marshallian hypothesis that co-location brings localization economies. The question that remains is how one can understand that many clusters persist over decades while the firms located in these clusters may not enjoy any benefit or actually suffer from co-location. Probably the most elaborated answer to this question comes from Olav Sorenson and colleagues in their work on US shoe manufacturing firms (SORENSON and AUDIA, 2000) and US biotechnology firms (STUART and Sorenson, 2003), where they combined entry and exit analysis. It was found that, in both industries, local density increased local entry rates. The authors argued that the spatial concentration of firms creates opportunities for new entrants by giving them access to 'tacit knowledge and social ties' (in particular, in the case of spinoffs). This means that regions with large populations of incumbents enjoy a 'regional advantage' in the sense that such areas experience the highest rates of entrepreneurship. Nevertheless, the performance of firms in such clusters is worse than firms outside these clusters, reflecting higher levels of competition. Thus, local density promotes entrepreneurship, yet worsened the performance of incumbents firms. This led Sorenson and colleagues to conclude that persistent clustering is not due to localization economies increasing firm performance but due to incumbents shaping opportunities for new entry which compensate for the higher rates of exit observed in clusters.

A final note on the dependent variable in all these studies. Most studies consider survival as the opposite of exit. However, apart from the shutting down of activity and bankruptcy, which are signs of failure, a 
firm may choose to exit the market by merging with or selling off to others. Indeed, new firms are often created with the explicit objective by entrepreneurs and venture capitalists to sell them to larger firms. Thus, exit is not necessarily equivalent to failure (FOLTA et al., 2006; STAM et al., 2008). There are a few studies addressing the different modes of exit in the context of industrial clusters. Weterings and MARsili (2013), using a competing risks model, estimate the effects of clustering on these two types of exit for Dutch new firms that entered the business services and manufacturing sectors in 1994-98. They find that clusters provide new firms with some better chances of survival, but more so, with better options for a potentially successful exit. These benefits, however, coexist, in certain cases, with crowding-out effects that set in beyond a threshold of geographic concentration and with increasing competition from the continuous entries of new firms in attractive clusters. An earlier study by Folta et al. (2006) found that - in the US biotechnology industry cluster size has a positive, but a declining effect on the rate of sell-offs. DE VAAN et al. (2013) looked specifically at the global video game industry and estimated a hazard model both for the probability to exit due to failure and for the probability to get acquired. $\mathrm{He}$ found that the main determinants that reduced the probability of exit by failure (pre-entry experience and users' quality assessment of the games) were also the main determinants that increased the probability of exit by acquisition, underlining the idea that acquisition is a sign of success.

\section{LIFE CYCLE APPROACHES}

Apart from the short-term relationship of clusters on industrial dynamics as discussed above, the long-term interplay between clustering and industrial dynamics has been an object of study as well. Here, the main quest in studies applying a long-term perspective is to understand how clusters emerge and how they evolve over time. Two research programmes applying a life cycle approach to industrial dynamics and economic geography are discussed below. The spatial product life cycle approach reasons from product life-cycle theory and derives the spatial evolution of an industry from the patterns of innovations that follow from the product's life cycle (Thompson, 1968). The industrial dynamics follow from a product's life cycle, where product standardization leads to scale economies and increasing market concentration. The spatial emphasis, then, is on the relocation patterns from core regions to peripheral locations as a product gets standardized and cost competition takes over product competition. The more recent industry life cycle approach explains how entire clusters can emerge from a single successful firm and subsequent spinoffs (KLEPPER, 2007). This approach focuses on the dynamics of entry and exit with special emphasis on spinoff firms. In this view, localization economies do not necessarily play any role in the formation of clusters over time. Rather, clusters emerge from a series of spinoff firms born from selected parent firms.

Both approaches make use of the life cycle concept as a biological metaphor. Note that the life cycle notion has a problematic deterministic flavour as if industries or clusters 'naturally' evolve from one stage to the next (MARtin and Sunley, 2011). Rather than viewing life cycle stages as predetermined successions, the concept of a life cycle is better understood as a heuristic device to organize empirical cases into a coherent framework without denying the indeterminate outcome of processes. For example, regarding the product life cycle notion, in some industries product standardization does not occur or only at a very late stage (MURMANN and Frenken, 2006), while in other industries the pattern of industry evolution may actually follow a reverse life cycle as it has been argued for service industries (BARRAS, 1986).

\section{Product life cycle approach}

The product life cycle is among the most long-lived of concepts in industrial dynamics dating back to the seminal work of VERNON (1966) in the field of international trade and of UTTERBACK and ABERNATHY (1975) in the field of innovation studies. The notion of a life cycle suggests that industries typically evolve in particular stages. In the explorative stage of an industry, entrepreneurs exploit the commercial opportunities of a new product by means of product innovation. At this stage, firms poorly understand technological possibilities and preferences of consumers. Progressive standardization in product design subsequently triggers process innovation. This marks the transition from the explorative stage to the mature stage of the product life cycle. The mature stage finally ends when all technological and market opportunities become depleted and decreasing returns to $\mathrm{R} \& \mathrm{D}$ set in.

The patterns of innovative activity bear important consequences for the industrial dynamics. Initially, many firms enter in an attempt to exploit the opportunities provided by the new product category. Over the product life cycle, firms learn how to scale their production and consequently raise the entry barriers for newcomers. Scaling is further facilitated by the emergence of industry-wide product standards otherwise known as 'dominant designs' (ABERNATHY and UTterback, 1978). Such standards lower product innovation and trigger process innovation. As a result, higher entry barriers limit further entry, and price competition forces less efficient firms to exit. This 'shakeout' phenomenon leads to a rapid fall in the number of participating firms, and the industry is transformed into a highly concentrated one (KLEPPER, 1996). 
There have been various attempts to test the product life cycle model systematically through the analysis of data on innovation and industrial dynamics (for an extensive overview, see MURMAnN and Frenken, 2006). Two main studies are worth mentioning. An extensive study by GORT and KLEPPER (1982) on the product life cycle dynamics of no less than 42 products found that net entry first rises and then falls, while entry is also positively correlated with the rate of innovation in agreement with the product life-cycle model. In a later study, UTTERBACK and SuAREZ (1993) went through studies on the history of eight technologies and found dominant designs to have emerged in six industries. In these industries, a rapid rise in the number of firms is observed before standardization took place, and a sudden fall in the number of firms hereafter. For the two technologies for which no standardization was observed, the number of firms did not fall rapidly.

There is a long tradition of studies in economic geography on the geographical implications of the product life cycle (THOMPSON, 1968; MARKusen, 1985; Davelaar, 1991; Duranton and Puga, 2001). Yet, studies have been less systematic and comprehensive than aforementioned studies. The main hypothesis would be that industries ${ }^{6}$ at an early stage in their life cycle are expected to be overrepresented in metropolitan core areas, while mature industries are expected to be overrepresented in peripheral areas. Clusters in an emerging industry will be located more often in metropolitan areas where capital, talent, early users and supporting institutions are more abundant. These factors provide the best breeding ground for product innovations and new firm formation. Mature industries with larger firms will disperse and locate more often in smaller towns in peripheral areas as to benefit from low wages, lower land prices and less stringent environmental regulations. In such environments, firms can more easily scale-up their operations by process innovation. As an industry moves from its explorative stage to its mature stage in its life cycle, the dominant location of an industry is expected to move from core to periphery (while the reverse may take place when an industry de-matures). Thus, the product life cycle theory predicts relocation patterns to be predominantly from core to periphery. ${ }^{7}$

Several studies based on longitudinal data have attempted to verify the process of spatial deconcentration and firm relocation. The study by MARKUSEN (1985) and a follow-up study by SORENSON (1997) both looked at dispersion patterns for a small number of US manufacturing industries, for the periods 195477 and 1954-87, respectively. They both found that the predicted pattern of increasing spatial dispersion over the product life cycle could only be validated in a limited number of industries. Also, using patent data for the period 1987-91, BRESCHI (2000) found that traditional industries like clothing, furniture, agriculture, and sports and toys display a pattern of increasing spatial dispersion, while 'science-based' industries like chemical industries and electronics remain highly concentrated. In a more recent study using employment data for French cities, PUMAIN et al. (2006) found that during the period 1960-2000 electronics, chemicals, textiles, metal products, machinery and equipment, and wood, pulp and paper industries all progressively relocated from the metropolitan cities to smaller cities. At the same time, metropolitan cities became increasingly specialized in R\&D over the period considered. Similarly, Duranton and Puga (2001) found that most French firms relocate from an area with abovemedian diversity (typically the large metropolitan areas) to an area with above-median specialization in the corresponding sector (typically the smaller cities). They also found that high-technology industries have a much higher share of relocations than mature sectors. In a study on Portuguese firms, Holl (2004) also found that start-ups are attracted by large diversified cities. Relocating firms, by contrast, were more attracted to location with a specialized industrial base and good highway accessibility. In a study on relocating firms in the Netherlands, Pellenbarg and VAN Steen (2003) found that most inter-regional relocations concern firms leaving the metropolitan core. For all these studies, the relocation patterns observed are consistent with the spatial product life cycle theory.

An additional explanation for the expected spatial life cycle pattern is based on different types of agglomeration economies and holds that metropolitan core areas are attractive for small innovative firms active in the explorative stage of the product life cycle due to the high density of other innovative firms generating knowledge spillovers, specialized supporting services and opportunities for collaboration (AUDRETSCH and FELDMAN, 1996). With the product still being in development, inter-industry spillovers ('Jacobs externalities') are relatively important as provided by the diversified nature of the core's economy. Thus, the many small firms active in the early stage of a product life cycle benefit most from the agglomeration economies generated in the core. Larger firms in mature industries, by contrast, rely more on in-house $\mathrm{R} \& \mathrm{D}$ aimed at process innovation and, therefore, would benefit less from being located in core metropolitan areas. And with the product being standardized and stable value chains being created, localization economies 8 (and intra-firm economies) become more important as provided in specialized clusters outside the core (HENDERSON et al., 1995; Duranton and Puga, 2001).

Evidence for such life cycle patterns were indeed found in a study by HENDERSON et al. (1995) analysing the growth of eight manufacturing industries in US cities. They found that new industries prosper in large diversified metropolitan areas while mature industries profit from being located in specialized cities. In line with this evidence, NefFKe et al. (2011a) used a Swedish plant-level dataset covering the period 1974- 
2004 and showed that the benefits industries derive from their local environment are associated with their stage in the product life cycle. Whereas localization economies increase with the maturity of industries, Jacobs externalities decline when industries are more mature. And by using a comprehensive database on Dutch firms of all sizes and all sectors, CAPASSO et al. (2011) found that information and communication technology (ICT)-related industries, as emerging industries, tend to be over-represented in the core or semiperiphery, while Fordist industries, as mature industries, were found to be over-represented in the periphery. Thus, the location patterns of innovative and mature sectors can be understood well in the light of the spatial product life cycle.

\section{Industry life cycle approach}

Contrary to product life cycle research, industry life cycle studies analyse industry evolution purely in terms of the underlying industrial dynamics of entry and exit of firms competing in a particular product market, i.e. an industry. The dynamics of innovation are not assumed to follow a certain pattern that is largely exogenous to firm behaviour. Rather, the product life cycle pattern of product innovation preceding process innovation can be logically explained by firm incentives: product innovation has a higher return for smaller firms than for larger firms, while the opposite holds for process innovation (KLEPPER, 1996). In contrast to product life cycle research, industry life cycle research explicitly takes the nature, especially the capabilities, of the firm as a key variable to be explained and as explanans for industry evolution (KLEPPER, 2002, 2011).

Following a demographic logic, industry life cycle studies describe industry evolution by the number of firms active in an industry at each moment in time, which equals the cumulative number of entries minus the cumulative number of exits. The spatial evolution of an industry can then simply be analysed by the spatial distribution of firms across regions. Here, the number of firms in a region at a particular moment in time equals the cumulative number of entries and inward-migrating firms minus the cumulative number of exits and outward-migrating firms.

The dynamics of spatial clustering follow from the location decisions of new entrants and the quality of their capabilities. New entrants most often have experience in the same or in a related industry. Following KLEPPER (2002), firms diversifying from a related industry can be called 'experienced firms' and entrepreneurs who set up a firm and previously worked as an employee in a related industry can be called 'experienced entrepreneurs'. 'Spinoffs' possess even more relevant pre-entry experience, as the employees who set up spinoffs firms have previously worked in exactly the same industry. Obviously, during the emergence of an industry, spinoffs do not exist, as potential parent firms are not yet active in the industry. That is why the first generation of entrants is typically composed of experienced firms and experienced entrepreneurs and, occasionally, of 'de novo start-ups' without any relevant pre-entry experience. Over time, the share of spinoffs increases at the expense of other types of entrants. This pattern can be understood from the increasing entry barriers created by successfully growing incumbent firms. Since spinoffs have the most relevant preentry experience, only these firms can overcome the entry barriers and compete with incumbents.

The dynamics of spatial clustering can now be understood as follows (Klepper, 2007; Buenstorf and KLEPPER, 2009). Firms are assumed to be heterogeneous in their capabilities, partly because of different pre-entry experience and partly because of idiosyncratic factors. Firms with capabilities that are best suited to deliver products that happen to fit market demand best will grow fastest and produce most spinoff firms. Spinoffs (be they from the same or a related industry) inherit a large part of the capabilities of their parent, which explains why successful firms tend to create successful spinoffs. Thus, following Darwinian logic (Boschma and Frenken, 2003), more successful firms produce more, and more successful, spinoffs. Since spinoffs tend to locate in the same region as the parent firm (KLEPPER, 2007; DAHL and SORENSON, 2009), a cluster emerges once a few successful firms start to create many successful spinoffs which, in turn, create successful spinoffs themselves. ${ }^{9}$ Once exit rates start to increase due to rising competition levels stemming from increasing economies of scale at the firm level, these firms will survive, while firms with less fit capabilities will have to exit. As a result, a cluster emerges in the region(s) where the initial successful parent(s) happen to have located in the past.

Indeed, KLEPPER (2007) could explain the emergence of the Detroit automobile cluster by interacting the spinoff and the Detroit variables, showing that spinoffs within the Detroit cluster outperformed spinoffs outside the cluster. The emergence of the Detroit cluster, then, can be attributed to the exceptional capabilities of Detroit spinoffs inherited from selected parents in Detroit. This methodology was also used in the studies on US tyre firms clustering in Akron, Ohio (Buenstorf and Klepper, 2009), and in Dutch publishing firms clustering in Amsterdam (HEEBELs and Boschma, 2011). In both cases, it was also found that spinoffs within the cluster outperformed spinoffs outside the cluster, suggesting that clusters emerged through the transmission of exceptionally fit capabilities from selected parent firms within the cluster. The success of a cluster, then, can be traced back to a single or a few successful parent firms that pass on their capabilities to several generations of spinoffs firms. It also means that clusters are expected to emerge even in the absence of localization economies. Indeed, once controlling for pre-entry experience, 
KLEPPER (2007) showed that Detroit firms did not have higher survival rates than firms outside Detroit. Other studies applying the industry life cycle framework came to the same conclusion. In the UK car industry (Boschma and Wenting, 2007), the global fashion industry (WENTING, 2008), the US tyre industry (Buenstorf and Klepper, 2009), the US semiconductor industry (KLEPPER, 2010), the German machine tool industry (BUENSTORF and Guenther, 2011), and the Dutch publishing industry (HEEBELS and Boschma, 2011), being located in a cluster did not increase the survival probability of firms. Only for the global video game industry (DE VAAN et al., 2013) and the Portuguese plastic injection moulds industry (Costa and BAPTISTA, 2011) were localization economies identified, but only once a cluster grew beyond a critical size. In the video game clusters, this threshold effect can be attributed to thick markets of flexible and specialized labour in the larger clusters, while in the plastic injection moulds industry localization economies are said to emerge only for large clusters with extensive vertical division of labour. ${ }^{10}$

This industry life cycle model and its spatial implications explain why there is 'regional path dependence' (Martin and Sunley, 2006; HenNing et al., 2013): since the first cohort of firms entering a new industry is not composed of spinoffs, but mostly by experienced firms and experienced entrepreneurs coming from related industries, regions that host industries that are related to the new industry have a higher probability to create this new industry. ${ }^{11}$ Telling examples of such an evolutionary process of regional branching (Boschma and Frenken, 2011) include the environmental sector emerging out of the coal and steel sectors in the Ruhr area of Germany (GRABHER, 1993) and the television receiver industry branched out of the radio industry in Chicago, Illinois (KLEPPER, 2006). Recently, evidence on the phenomenon of regional branching has been found using systematic statistical data, including studies on Swedish regions in the period 1969-2002 (NefFKe et al., 2011b), Spanish regions in the period 1988-2008 (BosCHMA et al., 2013), and US regions for the period 1977-97 (EsSletZBichler, 2013).

It should be stressed, however, that regional success in one industry is not automatically reproduced in the next industry, as the success of firms is only partly determined by pre-entry experience. As new industries also rely on newly created knowledge, the 'windows of locational opportunity' are open, at least to some extent, for any region (STORPER and WALKER, 1989; BOSCHMA, 1997). Yet, regions hosting related industries clearly enjoy an advantage because related industries provide a large pool of potential experienced firms and experienced entrepreneurs. So the emergence of new industries over space is, on the one hand, largely a chance event, but following Louis Pasteur's saying, 'chance favours the prepared mind', regions with an industry and knowledge structure that is related to the emerging industry have higher chances to develop such new industries (FELDMAN and FRANCIS, 2003).

\section{SUMMARY AND CONCLUSIONS}

This review started to define the field of industrial dynamics in a narrow sense as the study of entry, growth and exit of firms across industries. In the context of economic geography, the central question becomes how clusters of economic activity can be understood from the entry, growth and exit of firms, and how, in turn, clusters affect entry, growth and exit patterns through localization economies. This question was answered by reviewing how clusters affect entry, exit and growth through localization economies, and by applying a long-term perspective to the emergence and evolution of clusters.

The first conclusion that could be drawn holds that clustering has a strong effect on entry. Without exception, empirical studies found that entry rates increase with cluster size. Importantly, this empirical association does not in itself indicate that firms locate in a cluster because they benefit from co-location, since most potential entrepreneurs simply stay in their region of origin. This does not hold for the location choices of subsidiaries, e.g. in the case of foreign greenfield investment. For these studies, localization economies seem to play a role in entry decisions, but only for technologically lagging firms who have most to gain and least to lose from co-location (Shaver and Flyer, 2000; AlcÁcer and Chung, 2007).

The second main conclusion holds that there is only weak evidence that localization contributes to firm performance. More specifically, especially when performance is defined as survival, few studies find any indication for localization economies, while for studies defining performance as growth evidence on localization economies is more convincing. Furthermore, in those studies where firm age is included, the evidence supporting the hypothesis of localization economies on growth seems to hold in studies looking at young firms, while studies covering firms of all ages generally find no evidence or even negative evidence for this hypothesis. It can be argued that given the heterogeneity in capabilities between young and more established firms, young firms may profit more from co-location than older firms. Such an explanation, which remains to be tested more systematically, is in line with recent work on plant-level productivity by RIGBY and BROWN (2013) which showed that relatively new plants benefit more from localization economies than older plants.

A third finding concerns the role of related industries and their impact on firm performance. Even if firms do not necessarily benefit from co-location with firms that are active in the exact same industry, a number of studies 
show that co-location with firms active in related industries is beneficial for firms. This finding indicates that firms may experience negative externalities from colocation with same-industry firms due to involuntary knowledge spillovers and competition for critical resources such as talented employees, while they may experience positive externalities from co-location with related-industry firms as knowledge spillovers then occur to non-competing firms (STABER, 2001).

The findings of studies on where clusters emerge and how they evolve are less systematic (HENNING et al., 2013), since research designs and the data used are much less standardized compared with studies testing the effect of clustering on entry, growth and exit rates. Nevertheless, the available evidence is largely consistent with predicted patterns.

Concerning the spatial product life cycle, the main hypothesis holds that firms in emerging innovative industries profit most from being located in large diversified cities, while firms in mature routinized industries profit more from being in a cluster, and typically in smaller specialized cities. Indeed, the available evidence suggests that localization economies increase with the maturity of industries, while benefits from variety tend to decline when industries become more mature. Furthermore, work on firm relocation shows that the dominant pattern is from larger cities to smaller towns, indicative of firms that look for locations with lower prices for inputs as their technologies become standardized and competition shifts from quality competition to cost competition.

Evidence on the more recent industry life cycle theory and its emphasis on spinoffs dynamics as the main driver underlying cluster formation is also quite consistent. In line with the more general findings discussed in the subsection on firm survival, the industry life cycle studies find that localization economies have no effect on firm survival. Instead, as spinoffs outperform other firms, clusters emerge primarily from a local process of spinoff creation. This finding is not in line with the spatial product life cycle that expects firms in specialized cities to benefit from localization economies. However, these conflicting findings may be, at least, due to the fact that localization economies in industry life cycle studies are tested for all firms that ever exist during the whole life cycle of an industry, while localization economies in the spatial product life cycle are tested by looking at the later stages of the life cycle, i.e. after the shakeout has occurred with only relatively few firms still operating.

The industry life cycle model also explains why there is regional path dependence: since the first generation of entrants in a new industry hardly contain spinoffs, but mostly firms set up by people with experience in related industries, regions that host industries which are related to the new industry have a higher probability to create this new industry. Thus, even though the location of new industries can be sensitive to the random location of exceptional entrepreneurs who bring forth many generations of spinoffs, chance stills favours regions with industries related to the emerging industry. Since more diversified urbanized regions will have a higher likelihood of having one or more industries related to the new industry in question, new industries can be expected to emerge in such diversified areas rather than in specialized areas, in line with the spatial product life cycle theory.

\section{FURTHER RESEARCH}

From this review, a number of suggestions for future research that would lead to important refinements in theoretical frameworks, research design and empirical validity are now listed. One of the main challenges in future research lies in reconciling contradictory empirical findings. In particular, from this review it has become clear that the main gap in empirical understanding concerns the alleged effect of localization economies on firm performance as measured by firm growth and firm survival, which some may even consider the key question in economic geography at large. One reason that empirical findings did not converge is a lack of standardized methodologies, which prevents empirical evidence to be cumulative. Yet, even if methodologies become standardized, evidence on localization economies may still be inconclusive in case the underlying theoretical premise - that all firms profit equally from clustering and in the same manner - is fundamentally wrong. The second main challenge will thus be to 'open the black box' in statistical research on clustering so to arrive at a better theoretical understanding of the type of firms that benefit from localization economies and the conditions, mechanisms and spatial scale through which such benefits are realized.

Regarding methodology, it has been argued that a better understanding of localization economies would necessitate a higher degree of methodological standardization (WenNBerg and Lindqvist, 2010). Yet, it is important to recognize that lack of standardization is to some degree unavoidable since statistical data for different countries, industries or time periods do not always come at the same level of detail. Yet, more standardized methodologies are needed to arrive at an accumulation of evidence. A series of operational issues can be addressed in this context. First and foremost, the current use of various indicators of localization economies (including location quotients, same-sector employment, number of same-sector firms, and cluster dummies) is undesirable. Since externalities stemming from co-location of firms are being dealt with, the simple measure of the absolute number of firms seems most desirable (and, in fact, is most common). Note, however, that such a simple indicator is preferred only if more detailed data on the actual flows of goods, labour and knowledge between firms are lacking. 
Second, the industry definition is often taken from official statistics, while these generally do not capture relevant product markets. Thus, industry categorizations based on product data are to be preferred (cf. Klepper 2002, 2006, 2010; NefFKe et al., 2011b). Finally, this review highlighted the importance of differentiating between different modes of entry (de novo, spinoff and subsidiary) and different modes of exit (bankruptcy, voluntary, and merger and acquisition). The effect of clusters on these different types of events has been shown to be substantial and sometimes even opposite.

Another fundamental methodological problem remains the definition of the relevant geographical boundaries of clusters. When tracing the firm-level effects of localization economies, it seems more relevant to take distance from a cluster into account (MAINE et al., 2010). The relevant spatial level and spatial decay may well be different for different mechanisms underlying localization externalities (ROSENTHAL and Strange, 2001; WenNBERG and LindQVist, 2010). One recent study on high-technology firms in the US state of Texas found that co-location within 1 mile yielded localization diseconomies, while co-location between 1 and 25 miles yielded localization economies (DA Silva and МсCомB, 2012). Local labour market areas seem to be the obvious level of spatial aggregation so as to capture the Marshallian localization economies associated with specialized labour. Similarly, it can be argued that local labour market are also the main level at which knowledge spillovers occur, as such spillovers often stem from employees' social networks in the local area (BRESCHI and LisSONi, 2009), though some have argued that such spillovers are likely to occur primarily at smaller distances (ROSENTHAL and Strange, 2001) or longer distances (BotTAzzi and PERI, 2003; WOODWARD et al., 2006). To account for particular labour market institutions, such as the enforcement of non-compete covenants, it might be useful to include the regional level in the analysis as well (MARx et al. 2009). For what regards specialized suppliers, the relevant spatial level is more dependent on the specific industry. In most industries, the relevant spatial area is arguably much larger than local labour markets, except for industries characterized by time-sensitive production processes.

Apart from the methodological challenges in research on industrial dynamics and economic geography, it is also argued that theoretical advances are needed to understand better the exact mechanisms underlying localization economies and the differential effects such economies may have on different type of firms. The mixed evidence on localization economies has questioned the common wisdom that clustering necessarily benefits firms and that clusters come into existence because clustering benefits firms. The alternative evolutionary view explains clusters as stemming from a spinoff process. Indeed, quite a number of recent studies have shown that clusters emerge from a spinoff dynamic, even in the absence of localization economies. In the present authors' opinion, the main research challenge at the interface of industrial dynamics and economic geography is therefore no longer to look for evidence of localization economies by simply associating indicators of industrial dynamics with indicators of clustering, but rather to ask the question which type of firms profit from clustering and under what conditions?

One key assumption in almost all previous studies holds that all firms equally profit from co-location seems to be ill-founded. From an evolutionary economic perspective, a starting point in any analysis should be that firms are heterogeneous in their organizational capabilities and, hence, in their ability to profit from localization economies, on the one hand, and to contribute to such economies, on the other (GIULIANI, 2007a, 2007b). One hypothesis that follows holds that the less developed a firm's capabilities, the more it might potentially gain from being located in a cluster. In a recent study, RIGBY and BROWN (2013) indeed found such effects using various indicators for competences. A more refined hypothesis could be that the relationship between firm competence and localization economies is bell-shaped, with firms with intermediate levels of capabilities profiting most from clustering as some minimum capabilities are necessary to be able to absorb knowledge from nearby firms (COHEN and Levinthal, 1989; Pe'ER et al., 2008; VAN OORT et al., 2012). Such a hypothesis links to the literature on the location of multinational firms, where it has been argued that firms with the most advanced capabilities have most to lose to competing firms in a cluster (Shaver and Flyer, 2000), unless these are difficult and costly to learn by others (ALCÁCER and CHUNG, 2010). More generally, it is expected that clustering creates more benefits for de novo firms than for diversifying firms. While diversifiers can rely on in-house experience and past reputation irrespective of its location, for de novo firms a location in clusters provides spillover opportunities and signals legitimacy.

A further challenge is to distinguish between different mechanisms of localization economies, both theoretically and empirically (BRESCHI and LisSONI, 2001). In particular, an analysis of the various mechanisms that may underlie localization economies is also needed to test Marshallian theories of cluster advantage. That is, one would have to 'open the black box' of localization economies as currently measured by simple concentration or specialization measures and explicitly model localization economies by its three Marshallian components of specialized suppliers, thick labour markets and knowledge spillovers. Again, the study by RigBy and BROWN (2013) can serve as an example in the context of explaining firm performance, while one can turn to ALCÁCER and CHUNG (2010) for a study on firm location. 
Regarding the specific mechanism of knowledge spillovers, the use of network analysis on collaboration data has been shown to be promising. Giuliani showed in a series of studies on wine clusters (GIULIANI and Bell, 2005; Giuliani, 2007a, 2007b) that the knowledge-sharing network between firms indicates which firms are most central, and hence would profit most from co-location in clusters. Her study led to a number of follow-up studies on different industries (BOSChMA and Ter Wal, 2007; MOrRison, 2008; Kesidou and Romijn, 2008; Giuliani, 2011; TeR WAL, 2013). Another example is the use of social network analysis by BRESCHI and LissONi (2009) to analyse to what extent knowledge is flowing in networks of collaborating inventors, and by FLEMING and FRENKEN (2007) to map the evolution of clusters over time. PONDS et al. (2010) extended the knowledge production function with the specification of interregional networks of university-industry collaboration so to assess to what extent firms in one region benefit from university research in another region.

Regarding the evolutionary inspired life cycle approaches, the question that remains is how a single cluster develops over time. Interest in the evolution of clusters has grown rapidly over the last decade, as evidenced by case studies collected in various books (CURZIO and FOrTIS, 2002; BRESHNAHAN and GAMBARDella, 2004; Fuchs and Shapira, 2005; BRAUNERHJELM and FELdMAN, 2006; FornAHL et al., 2010). There is agreement that the topic of cluster life cycle deserves a different theory than the product or industry life cycle model, since the evolution of a single cluster will only be partially correlated to the growth of the industry in question (MENZEL and FornAHL, 2010; HubER, 2012). For example, a cluster's development may be driven by hype due to herding behaviour in location decisions (APPOLD, 2005; Dalla Pria and Vicente, 2006; Suire and ViCENTE, 2009). Furthermore, cluster development depends on localized collective action, e.g. setting up training institutes (BOSCHMA, 1997), in developing technical standards (VICENTE and SuIRE, 2007; VICENTE et al., 2011), mobilizing political and public support (SINE and LEE, 2009), and overcoming increased scarcity of land, labour and infrastructure (STAM and MARTIN, 2012). Systematic empirical data, however, documenting the industrial dynamics of particular clusters over long periods of time, have remained scarce (e.g., GARNSEY and HEFFERNAN, 2007), as such data generally cannot be collected with official statistics. Thus, to understand further the industrial dynamics underlying cluster life cycles, more systematic data collection is needed on the entry, growth and exit of firms as well as on their individual knowledge bases and network interactions.

In sum, there is a rich agenda for scholarly work in theoretical and methodological directions. On the one hand, future work will benefit from further methodological standardization, and explicit reflections upon such choices, particularly regarding definitions and measurement of localization economies and the choice of spatial and industry boundaries. On the other hand, a broadening and deepening of the theoretical frameworks is required to understand better the sources of cluster advantages and their effects on industrial dynamics. Both efforts would greatly benefit from more intense interaction between theoretical and applied scholars as well as between economists, geographers, management scientists and other social scientists.

Acknowledgements - This work was supported by Utrecht University (High Potential Grant - HIPO - to E. Cefis and K. Frenken); and by the University of Bergamo (grant ex. 60\%, number 60CEFI14, Department of Management, Economics and Quantitative Methods, to E. Cefis).

\section{NOTES}

1. This survey differs from related surveys such as those by Rosenthal and Strange (2004), De Groot et al. (2009), and Melo et al. (2009) in that these surveys mainly focus on the effect of agglomeration economies on regional growth, while the present survey focuses on the relation between localization economies and industrial dynamics (firm entry, growth and exit).

2. The question whether firms in clusters are more innovate than firms outside clusters is not dealt with in this review. Defining industrial dynamics in the narrow, demographic sense, the choice has been to focus only on entry, growth and exit of firms. For studies on the relation between clustering and innovation, see BAPTISTA and SWANN (1999), Beaudry and Breschi (2003), and Folta et al. (2006).

3. Importantly, not all studies in the organizational ecology tradition found that legitimation process are regionalized. BIGELOW et al. (1997) found that regional founding rates of automobile manufacturers were positively affected by national firm density only. Similarly, LOMI (2000) found for Danish banks that, with the exception of those in the capital, founding rates were affected by national firm density. Indeed, for service industries like banking, this can be understood from the cross-regional transfer of knowledge in multi-locational firms.

4. Though locational origins of founders may lie at the root of high entry rates in clusters, localization economies may still play a role in entry decisions. It can be analysed whether firms prefer to locate within or outside clusters in their particular region of origin. In a study controlling for region of origin, PE'ER et al. (2008) showed that most firms that enter are indeed drawn to clusters in their region of origin, suggesting that (perceived) localization economies played a role in location decisions. Localization economies may also play a role in foreign entry.

5. A related topic of research is whether firm growth is enhanced in regions with high knowledge intensity. Such an effect would be especially indicative of the knowledge spillovers as one of the mechanisms 
underlying agglomeration economies. STOUGH et al. (1998) investigated the economic development of the greater Washington, DC, area in the United States and found that a high concentration of technically skilled workers is associated with higher levels of new firm growth. RASPE and VAN OORT (2008) also found for all Dutch establishments that being located in a local innovative environment and an R\&D-intensive environment is more conducive to firm growth than being located in a region that is less endowed with knowledge resources. This can be considered as indirect evidence of agglomeration economies in the firm of knowledge spillovers.

6. Industries are collections of producers active in the same product market. This might lead to confusion about the difference between the product life cycle and industry life cycle labels, but in this review the distinction between product life cycle and industry life cycle is based on the differences in the underlying literature, which focus on different mechanisms explaining industrial dynamics and the spatial distribution of industries.

7. A similar reasoning underpins international trade theory in which the location of an industry is expected to move from high- to low-wage economies over its product life cycle (VERNON, 1966). The product life cycle theory of industrial location does not necessarily imply the relocation of a firm: the movement from core to periphery could also be realized by opening branch plants in the periphery and reducing employment in the core region (a trend found by DumAis et al., 2002), or by subcontracting activities from the core to new or existing firms in the periphery.

8. Otherwise known as Marshall-Arrow-Romer (MAR) externalities.

9. In a recent paper, BERCHICCI et al. (2011) showed for the disk drive industry that the location choice of spinoffs is not necessarily determined by the location of the parent, but also depends on the technological strategy of a firm.

10. However, in some industries clusters do not emerge despite the fact that spinoff firms were pervasive. Notably, only a low degree of spatial concentration has been observed in the US laser industry (KLePPER and SleEPer, 2005) and German laser industry (Buenstorf and Geissler, 2011). This 'anomaly' can been attributed to the presence of many submarkets in the laser industry, which limited competition among these markets, leaving room for many firms to survive in niches for a prolonged period of time (Bhaskarabhatla and KLepper, 2008).

11. Apart from being a source of new entrants, the presence of related industries may also benefit the performance of already existing firms. BoschmA and WENTING (2007), for example, showed that firms in the British car industry experienced higher survival rates in regions with high levels of employment in related industries. Interestingly, this effect disappeared when the industry matured, possibly reflecting that the knowledge and competences in the car industry had become more specific over time.

\section{REFERENCES}

Abernathy W. J. and Utterback J. (1978) Patterns of industrial innovation, Technology Review 80, 41-47.

Acs Z. J. and Armington C. (2002) The determinants of regional variation in new firm formation, Regional Studies 36, 33-45.

Acs Z. J., Armington C. and Zhang T. (2007) The determinants of new-firm survival across regional economies: the role of human capital stock and knowledge spillover, Papers in Regional Science 86, 367-391.

Agarwal R. (1998) Small firm survival and technological activity, Small Business Economics 11, 215-224.

Agarwal R., Echambadi R., Franco A. M. and Sarkar M. B. (2004) Knowledge transfer through inheritance: spin-out generation, development and survival, Academy of Management Journal 47, 501-522.

Alcacer J. and Chung W. (2007) Location strategies and knowledge spillovers, Management Science 53, 760-776.

Alcacer J. and Chung W. (2010) Location Strategies for Agglomeration Economies. HBS Working Paper No. 10-071, Harvard Business School (HBS), Cambridge, MA.

Aldrich H. E. and Fiol C. M. (1994) Fools rush in? The institutional context of industry creation, Academy of Management Review 19, 645-670.

Appold S. J. (2005) Location patterns of US industrial research: mimetic isomorphism and the emergence of geographic charisma, Regional Studies 39, 17-39.

Audretsch D. B. (1991) New-firm survival and the technological regime, Review of Economics and Statistics 7, 441-450.

Audretsch D. B. (1995) Innovation and Industry Evolution. MIT Press, Cambridge, MA.

Audretsch D. B. and Feldman M. P. (1996) Innovative clusters and the industry life cycle, Review of Industrial Organisation 11, 253-273.

Audretsch D. B., Houweling P. and Thurik R. (2000) Firm survival in the Netherlands, Review of Industrial Organization 16, 1-11.

Audretsch D. B. and Mahmood T. (1995) New firm survival: new results using a hazard function, Review of Economics and Statistics 77, 97-103.

Audretsch D. B., Santarelli E. and Vivarelli M. (1999) Start-up size and industrial dynamics: some evidence from Italian manufacturing, International Journal of Industrial Organization 17, 965-983.

BAPTISTA R. and SWANN P. (1999) A comparison of clustering dynamics in the US and UK computer industries, Journal of Evolutionary Economics 9, 373-399.

Barras R. (1986) Towards a theory of innovation in services, Research Policy 15, 748-772.

BeAudry C. and Breschi S. (2003) Are firms in clusters really more innovative?, Economics of Innovation and New Technology 12, 325-342.

Beaudry C. and Swann P. (2009) Firm growth in industrial clusters of the United Kingdom, Small Business Economics 32, $409-424$. 
Berchicci L., King A. A. and Tucci C. L. (2011) Does the apple always fall close to the tree? The geographic proximity choice of spinouts, Strategic Entrepreneurship Journal 5, 120-136.

Bhaskarabhatla A. and Klepper S. (2008) Submarkets, Industry Dynamics, and the Evolution of the U.S. Laser Industry. Mimeo. Carnegie Mellon University, Pittsburgh, PA.

Bigelow L. S., Carroll G. R. and Seidel M. D. L. (1997) Legitimation, geographical scale, and organizational density: regional patterns of foundings of American automobile producers, 1885-1981, Social Science Research 26, 377-398.

Boone, C. A. J. J. and van Witteloostuijn A. (1995) Industrial organization and organizational ecology: the potentials for cross fertilization, Organization Studies 16, 265-298.

Bоsснма R. A. (1997) New industries and windows of locational opportunity. A long-term analysis of Belgium, Erdkunde 51, 12-22.

Boschma R. A. and Frenken K. (2003) Evolutionary economics and industry location, Review for Regional Research 23, 183-200.

Boschma R. A. and Frenken K. (2006) Why is economic geography not an evolutionary science? Towards an evolutionary economic geography, Journal of Economic Geography 6, 273-302.

Boschma R. A. and Frenken K. (2011) Technological relatedness and regional branching, in Bathelt H., Feldman M. P. and Kogler D. F. (Eds) Dynamic Geographies of Knowledge Creation and Innovation, pp. 64-81. Routledge/Taylor \& Francis, London.

Boschma R. A., Minondo A. and Navarro M. (2013) The emergence of new industries at the regional level in Spain: a proximity approach based on product-relatedness, Economic Geography 89, 29-51.

Boschma R. A. and ter WaL A. L. J. (2007) Knowledge networks and innovative performance in an industrial district: the case of a footwear district in the South of Italy, Industry and Innovation 14, 177-199.

Boschma R. A. and Wenting R. (2007) The spatial evolution of the British automobile industry. Does location matter?, Industrial and Corporate Change 16, 213-238.

Bottazzi L. and Peri G. (2003) Innovation and spillovers in regions: evidence from European patent data, European Economic Review 47, 687-710.

Braunerhjelm P. and Feldman, M. P. (Eds) (2006) Cluster Genesis: The Origins and Emergence of Technology-based Economic Development. Oxford University Press, Oxford.

BRESCHI S. (2000) The geography of innovation: a cross-sector analysis, Regional Studies 34, 213-229.

Breschi S. and Lissoni F. (2001) Knowledge spillovers and local innovation systems: a critical survey, Industrial and Corporate Change 10, 975-1005.

BRESCHI S. and Lissoni F. (2009) Mobility of skilled workers and co-invention networks: an anatomy of localized knowledge flows, Journal of Economic Geography 9, 439-468.

Breschi S., Malerba F. and Orsenigo L. (2000) Technological regimes and Schumpeterian patterns of innovation, Economic Journal 110(463), 388-410.

Breshnahan T. and Gambardella A. (Eds) (2004) Building High-Tech Clusters: Silicon Valley and Beyond. Cambridge University Press, Cambridge.

Buenstorf G. and Geissler M. (2011) The origins of entrants and the geography of the German laser industry, Papers in Regional Science 90, 251-270.

Buenstorf G. and Guenther C. (2011) No place like home? Relocation, capabilities, and firm survival in the German machine tool industry after World War II, Industrial and Corporate Change 20, 1-28.

Buenstorf G. and Klepper S. (2009) Heritage and agglomeration: the Akron tyre cluster revisited, Economic Journal 119, 705-733.

Cantwell J. A. and Santangelo G. D. (2002) The new geography of corporate research in information and communications technology (ICT), Journal of Evolutionary Economics 12, 163-197.

Capasso M., Cefis E. and Frenken K. (2011) Spatial Differentiation in Industrial Dynamics. A Core-Periphery Analysis based on the Pavitt-Miozzo-Soete Taxonomy. Eindhoven Center for Innovation Studies (ECIS) Working Paper Series No. 11-01. ECIS, Eindhoven.

CARLSSON B. (1987) Reflections on industrial dynamics: the challenges ahead, International Journal of Industrial Organization 5, 133-148.

CARLSSON B. (1989) Industrial Dynamics: Technological, Organizational, and Structural Changes in Industries and Firms. Kluwer, Boston, MA.

Cattani G., Pennings J. M. and Wezel F. C. (2003) Spatial and temporal heterogeneity in founding patterns, Organization Science 14, 670-685.

CAVES R. E. (1998) Industrial organization and new findings on the turnover and mobility of firms, Journal of Economic Literature 36, 1947-1982.

Cefis E. and Marsili O. (2005) A matter of life and death: innovation and firm survival, Industrial and Corporate Change 14, 1-26.

Cefis E. and Marsili O. (2006) Survivor: the role of innovation in firm's survival, Research Policy 35, 626-641.

Cohen W. M. and Levinthal D. (1989) Innovation and learning: the two faces of R\&D, Economic Journal 99, 569-596.

Costa C. and Baptista R. (2011) Agglomeration vs. Organizational Reproduction: The Molds Cluster in Portugal. Mimeo, Technical University of Lisbon, Lisbon.

Curzio Q. and Fortis M. (Eds) (2002) Complexity and Industrial Clusters: Dynamics and Models in Theory and Practice. Physica, Heidelberg.

Da Silva D. G. and МсСомв R. P. (2012) Geographic concentration and firm survival, Regional Science and Urban Economics 42, 691-701.

Dahl M. S. and Sorenson O. (2009) The embedded entrepreneur, European Management Review 6, 172-181. 
Dahl M. S. and Sorenson O. (2012) Home sweet home: entrepreneurs' location choices and the performance of their ventures, Management Science, 58, 1059-1071.

Dalla Pria Y. and Vicente J. (2006) Interactions mimétiques et identité collective: gloire et déclin du Silicon Sentier, Revue Française de Sociologie 47, 293-317.

DavelaAr E. J. (1991) Incubation and Innovation. A Spatial Perspective. Ashgate, Aldershot.

De Groot H. L. F., Роот J. and Smit M. J. (2009). Agglomeration, innovation and regional development: theoretical perspectives and meta-analysis, in Capello R. and Nijkamp P. (Eds) Handbook of Regional Growth and Development Theories, pp. $256-281$. Edward Elgar, Cheltenham.

De Vaan M., Boschma R. A. and Frenken K. (2013) Clustering and firm performance in project-based industries: the case of the global video game industry, 1972-2007, Journal of Economic Geography 13, 965-991.

de Vaan M., Frenken K. and Boschma R. A. (2011) The Downside of Social Capital in New Industry Creation. Working Paper, Utrecht University, Utrecht (available at: http://mathijsdevaan.com).

Doms M., Dunne T. and Roberts M. J. (1995) The role of technology use in the survival and growth of manufacturing plants, International Journal of Industrial Organization 13, 523-542.

Dumais G., Ellison G. and Glaeser E. L. (2002) Geographic concentration as a dynamic process, Review of Economics and Statistics 84, 193-204.

Dunne P. and Hughes A. (1994) Age, size, growth and survival: UK companies in the 1980s, Journal of Industrial Economics 17, 115-140.

Duranton G. and Puga D. (2001) Nursery cities: urban diversity, process innovation, and the life cycle of products, American Economic Review 91, 1454-1477.

Essletzbichler J. (2013) Relatedness, Industrial Branching and Technological Cohesion in U.S. Metropolitan Areas. Papers in Evolutionary Economic Geography (PEEG) No. 13.07. Utrecht University, Utrecht.

Esteve-Pérez S., Sanchis A. and Sanchis J. A. (2004) The determinants of survival of Spanish manufacturing firms, Review of Industrial Organization 25, 251-273.

Evans D. S. (1987) The relationship between firm growth, size, and age: estimates for 100 manufacturing industries, Journal of Industrial Economics 25, 567-581.

Feldman M. P. and Francis J. (2003) Fortune favors the prepared region: the case of entrepreneurship and the capitol region biotechnology cluster, European Planning Studies 11, 765-788.

Figueiredo O., Guimaraes P. and Woodward D. (2002) Home-field advantage: location decisions of Portuguese entrepreneurs, Journal of Urban Economics 52, 341-361.

Fleming L. and Frenken K. (2007) The evolution of inventor networks in the Silicon Valley and Boston regions, Advances in Complex Systems 19, 53-71.

Folta T. B., Cooper A. C. and BAIK Y. S. (2006) Geographic cluster size and firm performance, Journal of Business Venturing 21, 217-242.

FornaHL D. (2003) Entrepreneurial activities in a regional context, in FornaHL D. and BREnNER T. (Eds) Cooperation, Networks and Institutions in Regional Innovation Systems, pp. 38-57. Edward Elgar, Cheltenham.

Fornahl D., Henn S. and Menzel M.-P. (Eds) (2010) Emerging Clusters. Edward Elgar, Cheltenham.

Frenken K., VAn OORT F. G. and Verburg T. (2007) Related variety, unrelated variety and regional economic growth, Regional Studies 41, 685-697.

Fritsch M. (2011) The effect of new business formation on regional development - empirical evidence, interpretation, and avenues for the further research, in FRITSCH M. (Ed.) Handbook of Research on Entrepreneurship and Regional Development-National and Regional Perspectives, pp. 58-106. Edward Elgar, Cheltenham.

Fuchs G. and Shapira P. (Eds) (2005) Rethinking Regional Innovation and Change: Path Dependency or Regional Breakthrough? Springer, New York, NY.

Garnsey E. and HefFernan P. (2007) The Cambridge high-tech cluster: an evolutionary perspective, in Frenken K. (Ed.) Applied Evolutionary Economics and Economic Geography, pp. 27-47. Edward Elgar, Cheltenham.

Geroski P. A. (1995) What do we know about entry?, International Journal of Industrial Organization 13, 421-440.

Geroski P. A. (2001) Exploring the niche overlaps between organizational ecology and industrial economics, Industrial and Corporate Change 10, 507-540.

GiUliani E. (2007a) The selective nature of knowledge networks in clusters: evidence from the wine industry, Journal of Economic Geography 7, 139-168.

GiUliani E. (2007b) Networks and heterogeneous performance of cluster firms, in Frenken K. (Ed.) Applied Evolutionary Economics and Economic Geography, pp. 161-179. Edward Elgar, Cheltenham.

GiUliani E. (2011) The role of technological gatekeepers in the growth of industrial clusters: evidence from Chile, Regional Studies 45, 1329-1348.

Giuliani E. and Bell M. (2005) The micro-determinants of meso-level learning and innovation: evidence from a Chilean wine cluster, Research Policy 34, 47-68.

Gompers P., Lerner J. and SChARfStein D. (2005) Entrepreneurial spawning: public corporations and the genesis of new ventures, 1986 to 1999 , Journal of Finance 60, 577-614.

Gort M. and Klepper S. (1982) Time-paths in the diffusion of product innovations, Economic Journal 92, $630-653$.

GRABHER G. (1993) The weakness of strong ties - the lock-in of regional development in the Ruhr area, in GRABHER G. (Ed.) The Embedded Firm, pp. 255-277. Routledge, London. 
Hall B. H. (1987) The relationship between firm size and firm growth in the US manufacturing sector, Journal of Industrial Economics 35, 583-606.

Hannan M. T., Carroll G. R., Dundon E. A. and Torres J. C. (1995) Organizational evolution in a multinational context: entries of automobile manufacturers in Belgium, Britain, France, Germany, and Italy, American Sociological Review 60, 509-528.

Heebels B. and Boschma R. A. (2011) Performing in Dutch book publishing 1880-2008. The importance of entrepreneurial experience and the Amsterdam cluster, Journal of Economic Geography 11, 1007-1029.

Henderson V., Kuncoro A. and Turner M. (1995) Industrial development in cities, Journal of Political Economy 103, 1067-1090.

Henning M., Stam E. and Wenting R. (2013) Path dependence research in regional economic development: cacophony or knowledge accumulation?, Regional Studies 47, 1348-1362.

Holl A. (2004) Start-ups and relocations: manufacturing plant location in Portugal, Papers in Regional Science 83, $649-668$.

HUBER F. (2012) On the role and interrelationship of spatial, social and cognitive proximity: personal knowledge relationships of R\&D workers in the Cambridge information technology cluster, Regional Studies 46, 1169-1182.

Kesidou E. and Romijn H. (2008) Do local knowledge spillovers matter for development? An empirical study of Uruguay's software cluster, World Development 36, 2004-2028.

KLepper S. (1996) Entry, exit, growth, and innovation over the product life cycle, American Economic Review 86, $562-583$.

Klepper S. (2002) The capabilities of new firms and the evolution of the U.S. automobile industry, Industrial and Corporate Change 11, 645-666.

KLEPPER S. (2006) The evolution of geographic structure in new industries, Revue de l'OFCE 97, 135-158.

Klepper S. (2007) Disagreements, spinoffs, and the evolution of Detroit as the capital of the U.S. automobile industry, Management Science 53, 616-631.

Klepper S. (2009) Spinoffs: a review and synthesis, European Management Review 6, 159-171.

KLepper S. (2010) The origin and growth of industry clusters: the making of Silicon Valley and Detroit, Journal of Urban Economics 67, 15-32.

Klepper S. (2011) Nano-economics, spinoffs, and the wealth of regions, Small Business Economics 37, 141-154.

Klepper S. and Sleeper S. (2005) Entry by spinoffs, Management Science 51, 1291-1306.

LLOYD P. and MASON C. (1984) Spatial variation in new firm formation in the United Kingdom: comparative evidence from Merseyside, Greater Manchester and South Hampshire, Regional Studies 18, 207-220.

Lomi A. (2000) Density dependence and spatial duality in organizational founding rates: Danish commercial banks, 1846-1989, Organization Studies 21, 433-461.

Maine E. M., Shapiro D. M. and Vining A. R. (2010) The role of clustering in the growth of new technology-based firms, Small Business Economics 34, 127-146.

Malerba F. (2006) Innovation and the evolution of industries. Journal of Evolutionary Economics 16, 3-23.

MALERBA F. (2007) Innovation and the dynamics and evolution of industries: progress and challenges, International Journal of Industrial Organization 25, 675-699.

Markusen A. (1985) Profit Cycle, Oligopoly and Regional Development. MIT Press, Cambridge, MA.

Marshall A. (1920). Principles of Economics. Macmillan, London.

Martin R. and Sunley P. (2006) Path dependence and regional economic evolution, Journal of Economic Geography 6, $395-437$.

Martin R. and Sunley P. (2011) Conceptualizing cluster evolution: beyond the life cycle model?, Regional Studies 45, 1299-1318.

Marx M., Strumsky D. and Fleming L. (2009) Mobility, skills, and the Michigan non-compete experiment, Management Science $\mathbf{5 5}, 875-889$.

Mata J. and Portugal P. (1994) Life duration of new firms, Journal of Industrial Economics 27, 227-245.

Melo P. C., Graham D. J. and Noland R. B. (2009) A meta-analysis of estimates of urban agglomeration economies, Regional Science and Urban Economics 39, 332-342.

Menzel M.-P. and Fornahl D. (2010) Cluster life cycles. Dimensions and rationales of cluster evolution, Industrial and Corporate Change 19, 205-238.

Morrison A. (2008) Gatekeepers of knowledge within industrial districts: who they are, how they interact, Regional Studies 42, 817-835.

Murmann J. P. and Frenken K. (2006) Towards a systematic framework for research on dominant designs, technological innovations, and industrial change, Research Policy 35, 925-952.

NANDA R. and Sørensen J. B. (2010) Workplace peers and entrepreneurship, Management Science 56, 1116-1126.

Neffre F., Henning M. and Boschma R. A. (2011b) How do regions diversify over time? Industry relatedness and the development of new growth paths in regions, Economic Geography 87, 237-265.

Neffre F., Henning M. and Boschma R. A. (2012) The impact of ageing and technological relatedness on agglomeration externalities: a survival analysis, Journal of Economic Geography 12, 485-517.

Neffre F., Svensson Henning M., Boschma R. A., Lundquist K.-J. and Olander L.-O. (2011a) The dynamics of agglomeration externalities along the life cycle of industries, Regional Studies 45, 49-65.

Nyström K. (2007) An industry disaggregated analysis of the determinants of regional entry and exit, Annals of Regional Science 41, 877-896.

Pe'er A., Vertinsky I. and King A. (2008) Who enters, where and why? The influence of capabilities and initial resource endowments on the location choices of de novo enterprises, Strategic Organization 6, 119-149.

Pellenbarg P. H. and van Steen P. J. M. (2003) Spatial perspectives on firm dynamics in the Netherlands, Tijdschrift voor Economische en Sociale Geografie 94, 620-630. 
Ponds R., van Oort F. G. and Frenken K. (2010) Innovation, spillovers, and university-industry collaboration: an extended knowledge production function approach, Journal of Economic Geography 10, 231-255.

Porter M. E. (1998) Clusters and the new economics of competition, Harvard Business Review 76, 77-90.

Pumain D., Paulus F., Vacchiani-Marzucco C. and Lobo J. (2006) An evolutionary theory for interpreting urban scaling laws, Cybergeo, article no. 343 (e-journal).

Raspe O. and van Oort F. G. (2008) Firm growth and localized knowledge externalities, Journal of Regional Analysis and Policy 38, 100-116.

RENSKi H. (2011) External economies of localization, urbanization and industrial diversity and new firm survival, Papers in Regional Science 90, 473-502.

Rigby D. L. and Brown W. M. (2013) Who benefits from agglomeration?, Regional Studies doi:10.1080/00343404.2012.753141.

Rosenthal S. S. and Strange W. C. (2001) The determinants of agglomeration, Journal of Urban Economics 50, $191-229$.

Rosenthal S. S. and StRAnge W. C. (2004) Evidence on the nature and sources of agglomeration economies, in HeNDERson J. V. and Thisse J.-F. (Eds) Handbook of Urban and Regional Economics, Vol. 4, pp. 2119-2172. Elsevier, Amsterdam.

Rosenthal S. S. and Strange W. C. (2005) The geography of entrepreneurship in the New York metropolitan area, Federal Reserve Bank of New York Economic Policy Review 11, 29-53.

Shane S. (2000) Prior knowledge and the discovery of entrepreneurial opportunities, Organization Science 11, 448-469.

Shaver M. and Flyer F. (2000) Agglomeration economies, firm heterogeneity, and foreign direct investment in the United States, Strategic Management Journal 21, 1175-1193.

Sine D. S. and Lee B. H. (2009) Tilting at windmills? The environmental movement and the emergence of the U.S. wind energy sector, Administrative Science Quarterly 54, 123-155.

Sorenson D. J. (1997) An empirical evaluation of the profit cycle theory, Journal of Regional Science 37, $275-305$.

Sorenson O. and Audia P. G. (2000) The social structure of entrepreneurial activity: geographic concentration of footwear production in the United States, 1940-1989, American Journal of Sociology 106, 424-462.

StABer U. (2001) Spatial proximity and firm survival in a declining industrial district: the case of knitwear firms in BadenWurttemberg, Regional Studies 35, 329-341.

StAм E. (2007) Why butterflies don't leave. Locational behavior of entrepreneurial firms, Economic Geography 83, $27-50$.

Stam E., Audretsch D. B. and MejaArd J. (2008) Renascent entrepreneurship, Journal of Evolutionary Economics 18, $493-507$.

Stam E. and Martin R. (2012) When High Tech Ceases to be High Growth: The Loss of Dynamism of the Cambridgeshire Region. Tjalling C. Koopmans Research Institute Discussion Paper Series No. 12-10. Utrecht University School of Economics, Utrecht.

Storey D. J. (1982) Entrepreneurship and the New Firm. Croom Helm, London.

Storper M. and Walker R. (1989) The Capitalist Imperative. Territory, Technology and Industrial Growth. Basil Blackwell, New York, NY.

Stough R. R., Haynes K. E. and Campbell H. S. (1998) Small business entrepreneurship in the high technology services sector: an assessment for the edge cities of the U.S. national capital region, Small Business Economics 10, 61-74.

StUART T. and SORENSON O. (2003) The geography of opportunity: spatial heterogeneity in founding rates and the performance of biotechnology firms, Research Policy 32, 229-253.

Suire R. and Vicente J. (2009) Why do some places succeed when others decline? A social interaction model of cluster viability, Journal of Economic Geography 9, 381-404.

SutTON J. (1997) Gibrat's legacy, Journal of Economic Literature 35, 40-59.

Ter Wal A. L. J. (2013) Cluster emergence and network evolution: a longitudinal analysis of the inventor network in SophiaAntipolis, Regional Studies, 47, 651-668.

Thompson W. R. (1968) Internal and external factors in urban economies, in Perloff H. S. and Wingo L. (Eds) Issues in Urban Economics, pp. 43-62. Johns Hopkins University Press and Resources for the Future, Baltimore, MD.

Utterback J. M. and Abernathy W. J. (1975) A dynamic model of product and process innovation, Omega 3, 639-656.

Utterback J. M. and SuArez F .F. (1993) Innovation, competition, and industry structure, Research Policy 22, 1-21.

Vaillant Y. and LAfuente E. (2007) Do different institutional frameworks condition the influence of local fear of failure and entrepreneurial examples over entrepreneurial activity?, Entrepreneurship and Regional Development 19, 313-337.

Van Oort F. G., Burger M. J., Knoben J. and Raspe O. (2012) Multilevel approaches and the firm-agglomeration ambiguity in economic growth studies, Journal of Economic Surveys 26, 468-491.

VAN Wissen L. (2004) A spatial interpretation of the density dependence model in industrial demography, Small Business Economics 22, 253-264.

VERNON R. (1966) International investment and international trade in the product cycle, Quarterly Journal of Economics 80, 190-207.

Vicente J., Balland P. A. and Brossard O. (2011) Getting into networks and clusters: evidence from the Midi-Pyrenean Global Navigation Satellite Systems (GNSS) collaboration network, Regional Studies 45, 1059-1078.

Vicente J. and Suire R. (2007) Informational cascades vs. network externalities in locational choice: evidences of 'ICT clusters' formation and stability, Regional Studies 41, 173-184.

Vivarelli M. (1991) The birth of new enterprises, Small Business Economics 3, 215-223.

WaGner J. (1994) The post-entry performance of new small firms in German manufacturing industries, Journal of Industrial Economics 17, 141-154.

Wennberg K. and Lindevist G. (2010) The effects of clusters of the survival and performance of new firms, Small Business Economics 34, 221-241. 
Wenting R. (2008) Spinoff dynamics and the spatial formation of the fashion design industry, 1858-2005, Journal of Economic Geography 8, 593-614.

Wenting R. and Frenken K. (2011) Firm entry and institutional lock-in: an organizational ecology analysis of the global fashion design industry, Industrial and Corporate Change 20, 1031-1048.

Weterings A. and Marsili O. (2013) Spatial concentration of industries and new firm exits: does this relationship differ between exits by failure and by M\&A?, Regional Studies doi:10.1080/00343404.2012.726708.

Wezel F. C. (2005) Location dependence and industry evolution: founding rates in the United Kingdom motorcycle industry, 1895-1993, Organization Studies 26, 729-754.

Woodward D., Figueiredo O. and Guimaraes P. (2006) Beyond the Silicon Valley: university R\&D and high-technology location, Journal of Urban Economics 60, 15-32. 